\title{
Mededelingen
}

\section{Tweejaarlijkse NVMO-prijs Beste Onderwijsinnovatie}

Op 17 november 2011, tijdens het NVMO Congres, zal de NVMO-prijs Beste Onderwijsinnovatie voor de eerste maal uitgereikt worden.

\section{Doel van de prijs}

- Stimuleren van excellente onderwijsinnovatie in het medisch onderwijs.

- Belonen van excellente onderwijsontwikkelaars in de medische onderwijskunde.

\section{De jury}

De jury voor de selectie van de Beste Onderwijsinnovatie bestaat uit deskundigen (leden van de NVMO) met ruime ervaring met onderwijsvernieuwing en actief als docent in Nederland of Vlaanderen.

De jury is als volgt samengesteld:

- Prof. dr. Rein Zwierstra (Groningen), voorzitter

- Dr. Ineke Wolfhagen (Maastricht)

- Dr. Arnout Jan de Beaufort (Leiden)

- Prof. dr. Roy Remmen (Antwerpen)

- Prof. dr. Jan-Hindrik Ravesloot (Amsterdam)

\section{Werkwijze}

1. Alle onderwijsinnovatieve projecten binnen het medisch onderwijs aan Hogescholen en Universiteiten in Nederland en België kunnen in beginsel meedingen.

2. Criteria, waaraan deze projecten zouden moeten voldoen, zijn:

een onderwijsvernieuwing die

a. zich onderscheidt van bestaande methoden, b. in de laatste vijf jaar is ontwikkeld,

c. zo nauwkeurig gedocumenteerd is dat hij uitvoerbaar is door anderen,

d. met succes sinds tenminste twee jaar wordt toegepast, hetgeen met evaluatieresultaten wordt gestaafd,

e. breder toepasbaar is dan binnen de eigen instelling,

f. beschreven is in een artikel in de medische onderwijsliteratuur (tenminste 'submitted').

De indiener kan een persoon of een groep personen zijn.

2. De jury oordeelt over de onderwijsinnovatie en betrekt daar naar eigen goeddunken al of niet externe reviewers bij.

3. Iedere onderwijsinnovatie die door iemand genoemd wordt als in aanmerking komend' en die voldoet aan de bovengenoemde criteria wordt beoordeeld door de jury. Deze stelt een nominatie van drie projecten op.

4. Een jurylid onthoudt zich van stemming als het project van dezelfde instelling afkomstig is, of als er een ander belangenconflict bestaat.

\section{Criteria voor deelname}

De projecten dienen uitgevoerd te zijn binnen een Nederlandse of Vlaamse Universiteit of Hogeschool. Het dient duidelijk te worden aangegeven wie de initiatiefnemer(s) is/zijn van het project. Met andere woorden, is het ingediende project ontwikkeld door één medewerker binnen het medisch onderwijs of door een team. De opleidingsdirecteur of een collega met een vergelijkbare bestuurlijke verantwoordelijkheid moet schriftelijk beargumenteren 
waarom het project meedingt naar deze prijs.

Het innovatie project dient te zijn ontwikkeld en geïmplementeerd in de periode twee jaar vóór indiening voor de prijs. Zodoende kan aan het criterium van duurzame invoering en evaluatie worden voldaan. De genomineerden en de opleidingsdirecteur, opleidingsbestuurslid of decaan, die het project indienen moeten lid zijn of worden van de NVMO.

\section{Oplegbrief}

Elke aanvraag dient vergezeld te gaan van een aanbevelingsbrief van de hand van de opleidingsdirecteur, van een opleidingsbestuurslid of van de decaan. Die brief behoort bij voorkeur de volgende elementen te bevatten:

- Argumentatie van de innovatieve waarde.

- Impact van de voorgestelde innovatie op de opleiding.

- Toekomstperspectieven van ingediende innovatie.

- Informatie over de indieners.

\section{Shortlist}

Alle ingezonden projecten voor de toekenning in 2011 zijn beoordeeld door de jury. De shortlist van de genomineerden in alfabetische volgorde is als volgt:

- De onderwijslijn professionele ontwikkeling. UMCG, Onderwijsinstituut Faculteit Medische Wetenschappen.

- Het SETQ systeem (Systematic Evaluation of Teaching Qualities). AMC, Onderwijsinstituut Medisch Specialistische Opleidingen.

- Training critical appraisal of a topic. MUMC, Onderwijsinstituut Faculteit Health, Medicine and Life Sciences.

Tijdens het NVMO congres zal de prijswinnaar worden bekend gemaakt, waarna de prijs zal worden overhandigd.

\section{Han Moll Penning 2012}

De Han Moll Penning is bij het 25-jarig bestaan van de NVMO in 1997 ingesteld. De penning wordt eens in de vijf jaar in het kader van het lustrum van de NVMO toegekend aan een persoon, die zich heeft onderscheiden op het gebied van de ontwikkeling en innovatie van het medisch onderwijs in Nederland en/of België. Met de prijs wil het bestuur van de NVMO het belang van hoogwaardig medisch onderwijs benadrukken en zijn waardering uitspreken voor de bijdrage daaraan van de betreffende persoon. Het domein van de penning omvat alle onderdelen van het medisch en gezondheidszorgonderwijs. De prijs bestaat uit een legpenning en een oorkonde.

De prijs wordt toegekend door het bestuur van de NVMO op voordracht van een onafhankelijke jury. De jury voor de Han Moll Penning bestaat uit een voorzitter en twee leden. De jury voor 2012 bestaat uit: mevr. dr. D.H.J.M. Dolmans (Universiteit Maastricht), prof. dr. P.M.J. Stuyt (UMC St Radboud) en de laureaat van 2007, prof. dr. H.J.M. van Rossum (VUmc).

Alle leden van de NVMO worden uitgenodigd de jury attent te maken op mogelijke kandidaten. Voordrachten, voorzien van een korte argumentatie kunnen gezonden worden aan de voorzitter van de jury, mevr. dr. D.H.J.M. Dolmans, Universiteit Maastricht, Capaciteitsgroep Onderzoek van Onderwijs, Postbus 616, 6200 MD Maastricht (D.Dolmans@maastrichtuniversity.nl).

\section{Ethische toetsing onderwijsonderzoek}

Toenemend worden door de medisch-onderwijskundige tijdschriften terecht eisen gesteld aan de ethische behandeling van proefpersonen - in de meeste gevallen docenten en studenten. In veel landen valt dit type onderzoek onder het aandachtsgebied van medisch-ethische toetsingscommissies (METC). Strikt genomen is hier echter niet sprake van medisch-we- 